the Sucrose group of carbo-hydrates, so easily assimilated in themselves, and so reudily convertible into fat, may possess, of retarding, arresting, and preventing those fatty degenerative changes of the intestinal mucous membrane and its glands which I as well as others have found, post mortem, as the last and most fatal pathological phenomena of chronic starvation.

As the themotic power of molasses, for similar reasons, is self-evident, it only remains for me to recommend it to the naval and merchant services, and again, in conclusion, to my professional brethren who may have the misfortune to meet with the diseases incident to famine, with the hope that it may prove as useful to my poor countrymen across the Channel as I think I have shown it to be to the people of India.

$$
\text { I am, Sir, yours, \&e., }
$$

D. H. CULLIMORE, F.R.C.S., M.K.Q.C.P. I., Late Residency Surgeon at the Court of the King of Burmah. Connaught-square, 7 th January, 1880.

\section{"ERRONEOUS IMPRESSIONS OF PRO- FESSIONAL WORK."}

\section{To the Editor of THE LANCET.}

SIR, - In an editorial note appended to my letter in to-day's LANCET you state that you were " not aware that the paragraph in a lay contemporary was written by Dr. Tibbits, or that he was responsible for the statement concerning electricity to which we took exception."

I beg to say that I did not write the paragraph in question, and that I knew nothing of it until I saw it, in common with yourself, in the ordinary course; also that I should not have troubled you with any communication had not the "statement concerning electricity" been quoted by your contemporary as an extract from the "aunual report of Dr. Herbert Tibbits." I am sorry to encroach again upon your space, but your note, if uncontradicted, would convey the impression that I write upon medical subjects in the lay press, a thing I have never done and never intend to begin doing.

$$
\text { I am, Sir, your obedient servant, }
$$

New Cavendish-street, W., Jan. 24th, 1880. HERBERT TIBBITS.

* * If Dr. Herbert Tibbits will look again at the paragraph which appeared in a lay contemporary, he will see that the passage cited by us, and to which we took and still take grave exception, as reflecting on "the majority of the medical profession," is not stated to be an extract or distinguished by quotation marks. However, the fact that it is an extract does not alter our opinion of it as a reflection on the profession. The matter must now drop.-ED. L.

\section{THE NAVAL MEDICAL SERVICE.}

\section{To the Editor of THE LANCET.}

SIR,-If the new Naval Medical Warrant has not ap peared before you receive this letter, I should feel much obliged by your publishing it.

In my opinion it cannot be too strongly impressed on the Admiralty that if the new Warrant simply gives the naval medical officers the same pay and retirement recently granted to the army surgeons, it will most certainly not induce any prudent man to enter the navy.

The Admiralty ought to seriously consider that if the Army and Navy Warrants were identical as to pay and retirement, the army medical officer in India would receive more than double the pay and allowances of the naval one on the sume station, or any other station. Most persons will concede, also, that the great majority of doctors would infinitely prefer eighteen shillings a day on shore to a pound a day and the restrictions and discomforts of ship life. Under such cireumstances, it requires no laboured argument to prove that if the navy desires to compete successfully, for one moment, with the army for medical candidates, the Admiralty must be prepared to offer more liberal pay and retirement than obtains in the army, and either a shorter period of service for retirement-to allow for the loss of time on compulsory half pay-or a fair portion of half-pay time to count as full-pay time. Without such concessions being granted it is perfectly idle to hope for candidates.
With regard to the question of cabins, which has been frequently discussed in THE LANCET: anyone conversant: with the service will know that it is requisite for the safety of the ship that the navigating officer should have a cabin as near the upper deck as possible; but, most decidedly, with this exception, cabins ought to be "given according to relative rank"; and chaplains, who have uo naval rank, preferring, for good reasons, to have none, most certainly onght not to have a cabin in preference to any other civilian, of whatever seniority or standing.

In conclusion, I think it would conduce very much to the content of the Naval Medical Department if exchanges were permitted, as in the army.

I enclose my card, and am, Sir, yours \&c.,

\section{INDIAN MEDICAL SERVICE.}

\author{
To the Editor of THE LANCET.
}

SrR,-In your issue of November 15th, you devote a leader to the Army Medical Department. My present purpose is to solicit your powerful advocacy for the removal of some real grievances of the Indian Medical Service. To begin with, it is a strictly military service, although certain officers are lent for the performance of civil duties. Yet, although a military service, it is the only department in which staff allowances are not granted. For example, the pay of a surgeon-major above twenty years' service is $1056 \%$. per mensem; this is the pay of rank. The consolidated pay laid down for charge of a regiment by an officer of this standing is $1000 r$, such consolidated pay being actually less than the pay of rank. True, the the medical officer is not mulcted for doing work, since he is permitted to draw the pay of rank; but is it not an anomaly that consolidated pay should be fixed at a rate which is practically useless, since it is never drawn? There is no staff pay for holding charge of a regiment. An officer receives $1056 r$. while waiting for a charge, and precisely the same sum when in charge. The pensions are old-world, and out of harmony with the time; those of officers of the A.M.D., although they may serve at home or in good climates, being actually higher. Surely the man who is compelled to serve in the tropics all his time, and whose sick leave does not count towards service, should have a higher iustead of a lower pension-at the very lowest \&l per diem after fifteen years' actual service. A Madras surgeon-major, in an able letter to Lord Cranbrook, treats of the past and present of the Indian Medical Service, and gives a fair estimate of its prospects. He therein clearly shows there is a "block," and conclusively proves that an immediate saving to the State of one hundred thousand per annum would result from pensioning off liberally one hundred surgeon-majors. According to his view the days of the service are numbered, and the sooner it is wound up the better. Supersession is the order of the day.

One word to intending candidates. The pay of rank of a surgeon is $286 \mathrm{r}$. per mensem; true, a charge may be held in a year or two, but more likely for the first five years the youngster will be bucketed about from pillar to post. Now 286r. a month, in consequence of the depreciation of the rupee, is under $£ 24$, which is scarcely a living for a gentleman in India.

I am, Sir, yours obediently,

M. A. D.

\section{PARIS.}

(From our own Correspondent.)

M. MAGNAN commenced his course of lectures on Nervous and Mental Pathology on the 18th instant, taking Aphasia as the subject of his opening lesson. Setting aside glossoplegia, glosso-ataxia, and other cases in which the instrument of speech is at fault, the lecturer confined his attention to the study of two forms of aphasia, depending upon disturbances occurring in the psycho-motor region of the brain. Of these, the first, verbal amnesia, would appear to resultfrom lesions either of the third frontal convolution or of the cortical part of the insula, and the function of speech is lost because its organic substratum is destroyed. In logoplegia, on the con- 